\title{
外来がん化学療法における薬㓮師の関与のあり方
}

\author{
日野美波理*，石井雅人，藤原聡子，松香直行，定金典明， \\ 森山雅弘，二神幸次郎，柴田和彦，五味田裕 \\ 岡山大学医学部・茵学部附属病院薬剤部
}

\section{Participation of Pharmacists in Outpatient Chemotherapy}

\author{
Bibari Hino*, Masato Ishii, Satoko Fujiwara, Naoyuki Matsuka, Noriaki Sadakane, \\ Masahiro Moriyama, Koujiro Futagami, Kazuhiko Shibata and Yutaka Gomita \\ Department of Hospital Pharmacy, Okayama University Medical and Dental School
}

$\left[\begin{array}{l}\text { Received December 18, 2003 } \\ \text { Accepted April 18, } 2004\end{array}\right]$

\begin{abstract}
Owing to the approval of reimbursement of fees for antineoplastic chemotherapy on an outpatient basis by the national health insurance scheme in April 2002, an antineoplastic chemotherapy room was set up in the ambulatory area of our hospital in August 2000. In order to ensure the effective use of the safety cabinet and other existing equipment and the safe administration of antineoplastic agents to patients, the authors assigned a mixing pharmacist and a coordinating pharmacist who was to be in charge of antineoplastic chemotherapy for outpatients.

First, the mixing pharmacist prepared IV mixtures of the antineoplastic agents and auxiliary medicines in a sterile area and then the coordinating pharmacist audited the mixtures and carried them to the antineoplastic chemotherapy room. Other functions of the coordinating pharmacist included providing pharmaceutical care to patients and cooperating with doctors, nurses and other pharmacists involved in the chemotherapy. They also searched for information on individual medical charts or in patient statements and pointed out doubtful records or potential problems that might affect chemotherapy. Coordinating pharmacists notified 50 potential problems between August 2002 and April 2003.

To evaluate our pharmaceutical practices in outpatient antineoplastic chemotherapy, we conducted a questionnaire survey of the patients. Their responses indicated that our pharmaceutical care program was working well and that they hoped we would continue it. However, the usefulness of our program was not entirely clear to all patients and we recognized the need to better inform patients concerning this.
\end{abstract}

Key words — chemotherapy, outpatient, coordinating pharmacist, antineoplastic agents, questionnaire

\section{緒 言}

平成14年 4 月より，外来患者に対して悪性腫瘍の治療 を目的として，専用室で抗悪性腫瘍薬の投与などがなさ れた場合, 外来化学療法加算300点の保険算定が可能と なった。岡山大学医学部・歯学部附属病院 (以下, 当院 と略す)では同年 8 月に外来がん化学療法室を設置し, 医師，薬剤師，看護師の連携によって，外来の悪性腫瘍 患者に,より安全な治療の提供に努めることになった ${ }^{11}$.

外来がん化学療法を行うチーム医療に, 薬剂師の参画 が求められている。薬剤師が無菌的混合調製の面で参加 し, 処方鑑査を通じて薬学的管理を行うことは可能であ る。しかしながら, がん化学療法に携わる薬剤師は, 適
\end{abstract}

正使用の遂行およびリスクマネージャーとしての役割が 大きく2,3), 薬剤師による薬を介しての患者ケア，すな わちファーマシューティカルケアの実践が望まれる。一 方, 医薬品の臨床試験である治験において, 薬剤師は治 験コーディネーターとして，患者，医師，治験依頼者の 中に入って治験が円滑に実施されるようコーディネート し 3 者間の調整を図る役割を担っている。そこで当院で は，外来がん化学療法に関わる薬剂師として調製担当薬 剤師，医師，看護師ならびに患者の間に入って調整する 役割を有する外来がん化学療法コーディネート薬剤師 (以下，コーディネート薬剤師と略す)を企画し配置し た。これまでコーディネート薬戍師を配置して外来がん 化学療法に対応している報告はない.コーディネート薬 版師を配置することによって既存の設備を有効に活用 
し，抗悪性腫瘍薬処方の薬学的管理ならびに患者中心で 臨機応変に対応できる体制を構築した。今回，業務体制 の構築とともに薬凨師の関与に対する評価を, 疑義照会 の記録および患者アンケートに基づいて解析したので報 告する。

\section{方法}

外来がん化学療法業務体制の構築と各医療スタッフの 役割について示す.

平成14年 8 月に外来がん化学療法室として外来診療棟 の 4 階に 8 床が設置され, 専任看護師が 1 名配置され た。実施診療科については, 平成 14 年 8 月に試験運用と して外科を開始し，9月に内科，脳神経外科，虍膚科， 泌尿器科，産婦人科の運用を開始した。

処方オーダから投薬までの流机について図 1 に示し， 各医療スタッフの業務への関わり方について解説する. また，コーディネート薬剤師業務の手順書を図 2 に,
コーデイネート薬剤師の役割を図 3 に示す。

\section{1. 予約注射オーダ(主治医)}

主治医は可能なかぎり患者来院日の前日までに注射薬 の予約オーダを行う．多くの症例において，予約オーダ が入力される.外来がん化学療法室で投薬を行う場合「薬 剤部で混合調製」というコメント入れ，外来診療科で害 施する注射指示と区別している．患者来院当日に施行が 決定した場合，あるいは変更になった場合，注射オーダ はその度入力される。

\section{2. 処方せん出力, 計数調剤・処方せんの鑑査(注射薬 補給室配属の薬剤師・コーディネート薬剤師）}

予約オーダが入力されている場合，施行前日に注射薬 補給室配属の薬凨師が計数調剤および処方せんの鑑査を 行う。患者来院当日に医師による処方オーダの入力があ り，実施決定の処方せんの控えのFAXを受信した場合 は，コーディネート薬剤師が注射薬補給室で計数調剂 し，注射薬補給室配属の薬剤師の鑑査を受ける。

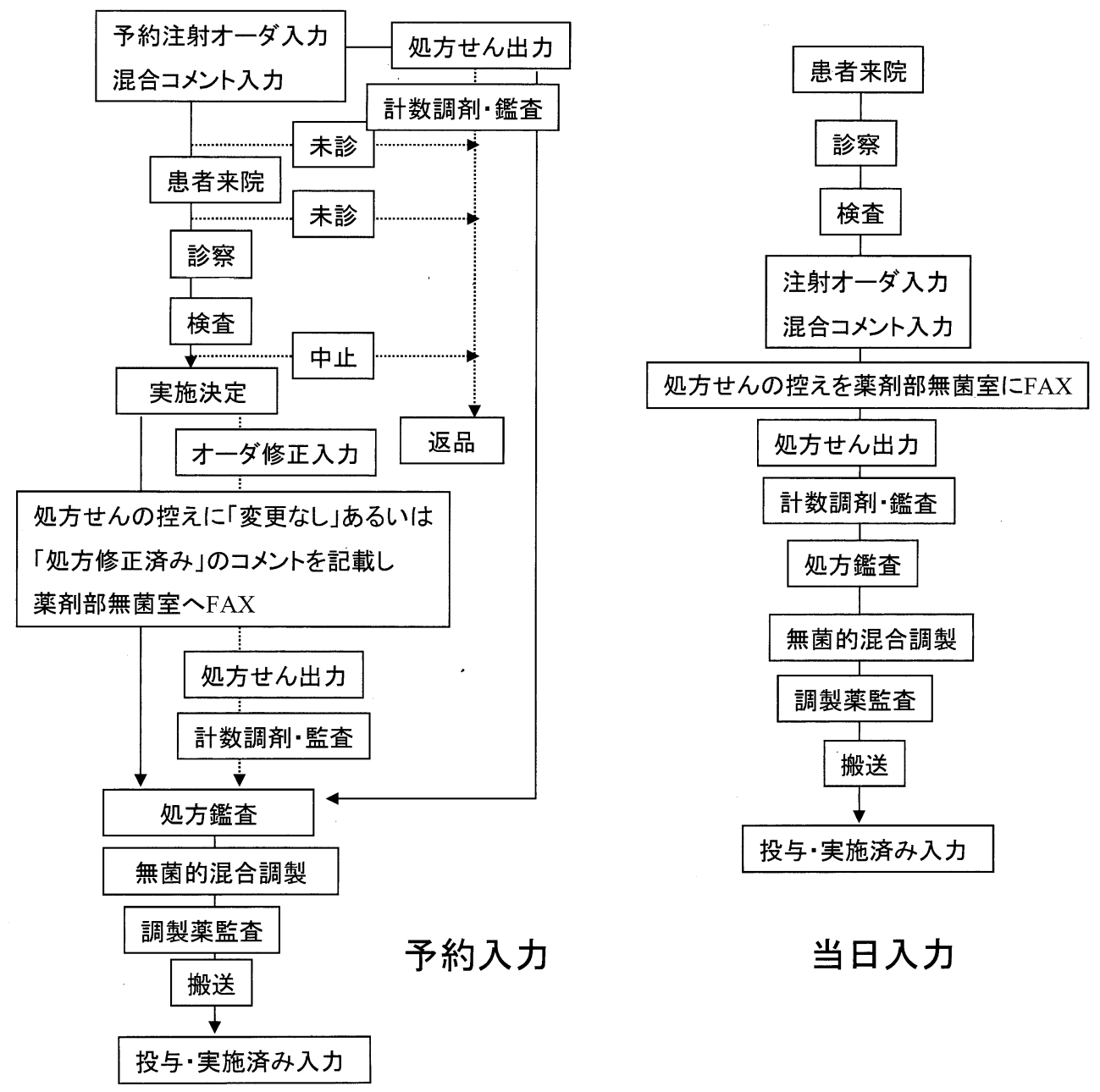

図 1. 処方オーダーから投薬までの過程におけるコーディネート 薬剂師の関与 
外来化学療法室コ一ディネート薬剤師業務手順書

平成 14 年 8 月

＜調製後処方監査〉

・空バイアル、残液量(使用済みシリンジ、空バイアルは無菌室に返却)の確認

・ボトル(あるいはシリンジ)とラベルと処方せんおよびFAX(処方せんの控え)の記載事項の照合

・遮光袋に薬剤を入れて外来がん化学療法室に搬送

〈カルテからの患者情報の転記事項＞

- 病名

・体重、体表面積

・ プロトコール

- 検査值

・基礎疾患 (DM、心機能障害、腎機能障害、肝機能障害など)

・過去の治療歴、副作用歴

《業務内容 $>$

1) 業務準備

・予約のある処方の確認(処方チェックおよび調製準備)

2) 10 時に行うこと

・無菌室の準備(空調、安全キャビネットの電源など)

- 外来がん化学療法室で担当看護師との打ち合わせ、現状把握

3）予約のある患者への対応

・最初の患者のFAXを送ったら各診療科からポケベルまたはPHS が入る

・確定のFAXを取りに行く(処方内容「変更なし」の記載を確認)

－調製前の処方鑑査済みの注射薬セットの内容を確認し(前投薬も含む)を無菌室に運ぶ

4) 変更のある患者への対応

- FAXの内容を確認し処方鑑查

・変更後の処方箋を打ち出して注射薬を取り揃え、注射薬補給室で監査を受ける

・ 注射薬セットを無菌室に運ぶ

・準備していた変更前の薬剤の返却と処方せん、ラベルの処理

5) 新規(予約なし)の患者への対応

- FAXの内容を確認し処方鑑査

- 処方嘎を打ち出して注射薬を取り揃え、注射薬補給室で監査を受ける

・注射薬セットを無菌室に運ぶ

6 ) 調製済み薬剂の交付

・調製担当薬剤師からポケベルまたはPHSが入る

－無菌室のパスボックスから注射薬セットを取り出し、く調製後処方監查〉を行う

- 外来がん化学療法室にて、担当看護師と処方内容とラベル記載事項の照合

・交付受け取り印を看護師にもらう

7）業務終了後の集計および記録

図 2. コーディネート薬剤師業務手順書

\section{FAX 送信 (主治医)}

当日, 主治医は診察・血液検査後, 化学療法実施決定 とともに「変更なし」あるいは「処方修正済み」と記載 した処方せんの控えを薬片部にFAX 送信する.

\section{4. 処方鑑査 (コーディネート薬剤師)}

コーディネート薬剤師は, 薬剤部で打ち出した処方せ んの内容と FAX で送られた処方せんの控えの内容が同 じであるか確認し, 用量, 投与経路, 投与時間, 配合変
化，必要な補助薬の有無，投与順序などを確認し，必要 に応じて医師に疑義照会を行う。また，薬品情報室や製 薬会社などと連絡をとり疑義問題に対応することもあ る。そのような状況に備え, 薬剤師は常にポケベルまた はPHS を携帯し, 医師・看護師・調製担当薬剂師と連 絡を取れる体制をとっている。

\section{5. 無菌的混合調製 (調製担当薬剤師)}

調製担当薬剤師は, 無菌室のパスボックスから処方せ 


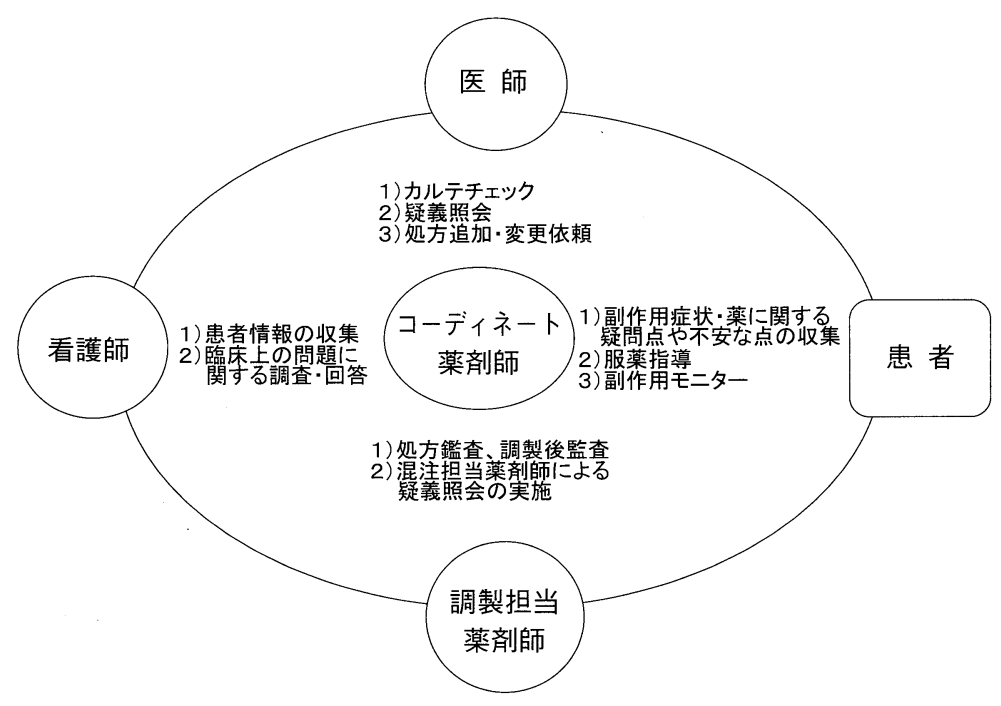

図 3. 抗がん剤化学療法におけるコーディネート薬剤師の役割

ん, ラベル, 薬品を受け取り, 調製を開始する. 調製前 後で自己監査を行う.疑義が生じたときは, コーディネー 卜薬剤師に連絡する。

\section{6. 調製薬監查および搬送(コーディネート薬剤師)}

無菌的混合調製終了後コーディネート薬剂師は空バイ アル・アンプルおよびシリンジによって調製後の監査を 行い, 問題がなければ前投薬を含む抗悪性腫瘍薬を患者 1 名分ごとに外来がん化学療法室に搬送する。外来がん 化学療法室において, カルテの記載内容から検査值など を確認し，処方漏れやオーダミスの有無などについて， 必要に応じで疑義照会を行っている. また, 副作用防止 目的で処方の追加および変更を依頼する場合もある。

看護師と患者情報を共有し，また配合変化など臨床上 の問題に関する薬学的調查・検討を行う.ささらに, 患者 に対して服薬指導や副作用モニターを行う．直接ベット サイドで投薬に関する質問を受けることもある。

\section{7. 記録(コーディネート薬㓮師)}

搬送終了後, カルテチェック, 患者への服薬指導など を行い患者情報記録用紙(表 1) に記入する。患者情報記 録用紙には，疾患名，体重，患者のプロトコール，実施 処方せん，処方変更とその理由，疑義照会の内容，調製 時の注意，患者からの訴元，内服薬などの情報を記録す ることとした.

薬剤部による無菌的混合調製の実施時間は，10時まで は製剤室配属の薬剤師が担当することとし，依頼の多い 10時から14時までの間は, 外来がん化学療法担当薬剤師 (コーデイネート薬剤師掞よび調製担当薬片師)が各 1 名 で担当することにした，14時以後は各外来診療科で対応
している.

そこで，業務体制を構築した後の業務量について，1 日平均患者数, 1 力月の実施延べ患者数および調製件数 (輸液 1 ボトルを 1 件とする)を調査した。調查期間は, 実施開始時である平成14年 8 月から平成15年 4 月までの 9 カ月間とした。な押，無菌的混合調製にかかった時間 は, FAX 受信から搬送完了までの時間とし, 平成15年 1 月の 1 力月間の平均值 $($ mean \pm S.D.) で示した. 患者は 診察が終了し化学療法実施決定後(この時点で, 通常, 処方せんの控えがFAX 送信される)に各診療科から外来 がん化学療法室に移動するため, 無菌的混合調製にか かった時間はほぼ患者待ち時間に相当する。化学療法実 施決定の FAX 送信を医師が忘れている場合などで，患 者待ち時間がさらに延長する可能性がある.

次に，疑義照会の記録打よび患者情報記録などを用い て, 外来がん化学療法に対する薬剤師の評価, 特にコー ディネート薬戍師を配置した利点について検討した。さ らに, ベットサイドで患者に接するコーディネート薬椷 師の役割を患者アンケートに基づいて解析した.アン ケート用紙を図 4 に示す．アンケート実施期間は平成15 年 3 月 26 日から平成 15 年 4 月 25 日までの 1 力月間とし た. 対象は外来がん化学療法室で治療を受けている患者 で，外来がん化学療法室の利用回数抒よび診療科は問わ ないこととした。

\section{結果・考察}

がん化学療法に携わる薬剤師は, 医薬品の品質管理, 患者情報・投薬管理および医療経済への貢献が期待で き，薬戍師の存在意義を示すことが出来ると考えられ 
表 1. 患者情報記録用紙

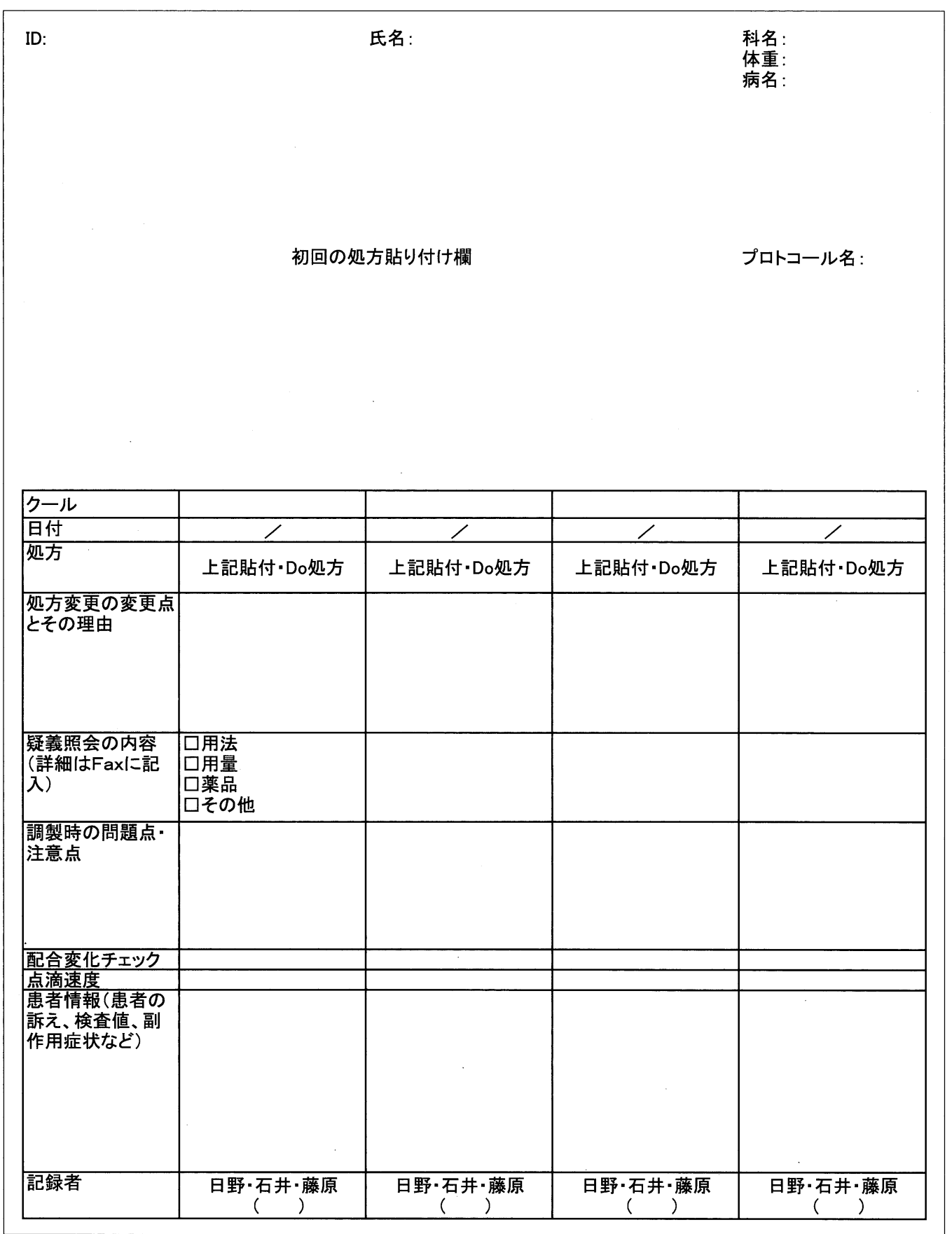

る ${ }^{1-6)}$.さらに, 薬剂師は顔の見える薬剤師として患者 の不安解消あるいは副作用モニタリングを通じて患者 サービスに貢献しなければならないと考える。そこで今 回, 当院では外来がん化学療法において医師，看護師な らびに患者の間に入って調整する役割を有するコーディ ネート薬剤師を配置し, 既存の設備を有効に活用し, 抗 悪性腫瘍薬処方の薬学的管理ならびに患者中心で臨機応 変に対応できる体制を構築した。

\section{1. 抗悪性腫瘍薬混合調製業務の実績}

1 日平均患者数は, $8 \sim 10$ 月：4.8名, 11〜 1 月：6.5
名， 2 ～月：6.2名であった. 1 力月間の実施患者数 および無菌的混合調製件数を図 5 に示す。実施患者数や 無菌的混合調製件数が最初の 3 力月は急激に増加した が，その後若干下降し，再度増加傾向を示している。

無菌的混合調製にかかった時間に関して, 平成15年 1 月の平均值 (mean \pm S.D.) としては FAX 受信から搬送完 了までに，前日までの予約オーダがない場合 $28 \pm 15$ 分で あり，予約オーダがある場合 $22 \pm 12$ 分であった，外来が ん化学療法室開設から 9 力月間で, 最大患者数は 1 日 12 名であった。 
点滴治療室患者さまアンケート

平成 15年3月

点滴治療室がスタートして約半年が経ちました。私たち薬剤師は先生や看護師さんたちとともに、前 例のあまりないところから点滴治療室での活動に取り組んでまいりました。現状を見極めて、問題点 を見つけ出すため、アンケートを実施させていただきたいと思います。患者様が日ごろ思っていらつしや ることをお聞かせください。ご協力よろしくお願いいたします。（該当個所を○で囲む、または、意見をご 記入ください)。

Q1 : 年齢は？性別は？
$1: 20 \sim 30$ 歳
$2: 31 \sim 40$ 歳
$3: 41 \sim 50$ 歳
$4: 51 \sim 60$ 歳
$5: 61 \sim 70$ 歳
$6: 71$ 歳以上
1 : 男
2:女

Q2:点滴治療室で治療を受けるのは今回で何回目ですか?
$1:$ 初めて
2:2 4回
3:5 10 回
4:11回以上

Q3 : 診療科は?
1 : 第 1 外科
2:第2外科
3: 婦人科
4 : 泌尿器科
5: 皮膚科
6 : 第 1 内科
$7:$ 第 2 内科

Q4 : 点滴治療室において薬剂師が行っていることで知っていることは (複数回答可)

$1:$ 何も知らない

2：2人1組でチームを作り、1人が無菌的な環境で調製し、1人が運んでいる

3:薬剤師が運んでいる

4 : 投与量、投与方法や混ぜてもいいかどうかの確認を行っている

5 : 問題点があるときは医師とお話をして、いいかどうか確認している

6 : 薬剂師が参加していることを知らない

$7:$ その他(

Q5: 待ち時間についての印象
$1:$ :とも遅い 2 :遅い $3:$ 適当

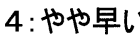
$5:$ 早い
6:日によって早かったり遅かったり

Q6 : 最大どのくらいまでなら待てますか?
$1: 15 \sim 30$ 分 $2: 30 \sim 45$ 分
$3: 45 \sim 60$ 分
$4: 60 \sim 75$ 分 $5: 75 \sim 90$ 分
$6: 90$ 分以上

コーディネート薬剤師および調製担当薬剂師と仕事を 分担した場合の欠点として，調製担当薬剂師のみが 1 名 で調製を行うため依頼が重なった時に時間がかかるコス トや，注入する薬液量を事前に確認してもらえない，な どが考えられな、1日12名受けた場合などでは，実施 FAXを同時に多く受けるので無菌的混合調製に時間が かかりすぎると判断し，予備の担当者に無菌的混合調製
の応援を求めることで状況を改善できた。また，監査に 関しては，コーディネート薬剤師が処方せんへあらかじ め調製量を記載し(例えば，1バイアル $2 \mathrm{~mL}$ の薬剤を

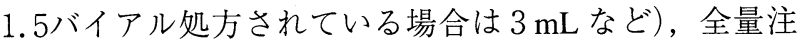
入ではないことを調製担当薬剂師に警告し，調製終了後 にシリンジ・バイアル内の残液量を確認した。

コーディネート薬剤師および調製担当薬剤師の役割分 
(図 4 のつづき)

Q7: 待ち時間についての感想

$1:$ 薬剂師が処方のチエックを行い無菌的に混ぜているので現状のままでよい

2 : 外来診察室で行っていた以前のほうがよかった

3: 現状のままでよいが、もう少し早くしてほしい

$4:$ :他(

)

Q8: 待ち時間のお知らせについて

$1:$ 待ち時間の情報をぜひとも教えてほしい

$2:$ 待ち時間の情報は特に必要ではない

Q9:薬を運んでいる薬剂師(コーディネート薬剤師)に望むこと(複数回答可)

$1:$ 薬の相談にのってほしい(点滴治療室で受けているお薬)

2 : 薬の相談にのってほしい(飲み薬や他の病院でもらっているお薬などお薬全般)

$3:$ 薬の情報がほしい(副作用)

$4:$ 薬の情報がほしい(生活上の注意点)

$5:$ だ早く運んでくれたらいい

$6:$ そ他(

Q10: 薬を運んでいる薬剤師 (コーディネート薬剤師)の印象(複数回答可)
$1:$ 話かけづらい
2: 話しかけやすい
1 : 話をしてみたい
2 : 話をしてみたいとは思わない
$1:$ 親しみがある
$2:$ 親しみがない
$1:$ 頼りになりそう
2: 頼れそうにない
1 : 自分たちのためにがんばってくれている
2: 何をしているかわからない
$1:$ 薬剂師の顔はわかる
$2:$ 他の職種と薬剂師の区別がつかない

その他(

)

Q11: 点滴治療室に薬剤師がいてよかったと思ったことがありましたら具体的に書いてください

Q12: 点滴治療室に来る薬剤師に対するご不満やご要望、ご意見などがありましたら具体的に書 いてください

図 4.アンケート用紙

担を行った利点としては，調製と搬送が同時にできて， 無菌室内外の人の出入りが最小限になることがあげられ る。また，コーディネート薬剤師は無菌的混合調製作業 を行わないので疑義照会など外部 (主治医や薬品情報室 など) との連絡が容易にでき, 患者に近い立場で患者情
報収集や副作用モニタリングなど患者サービスに貢献で きる点もあげられる，患者に対して，今回薬剤師が患者 に直接関与して患者の不安および症状を軽減した例もあ り，患者サービスに貢献できたと考えている，実際，患 者に服薬指導をする際に得た情報に基ついて，医師に疑 


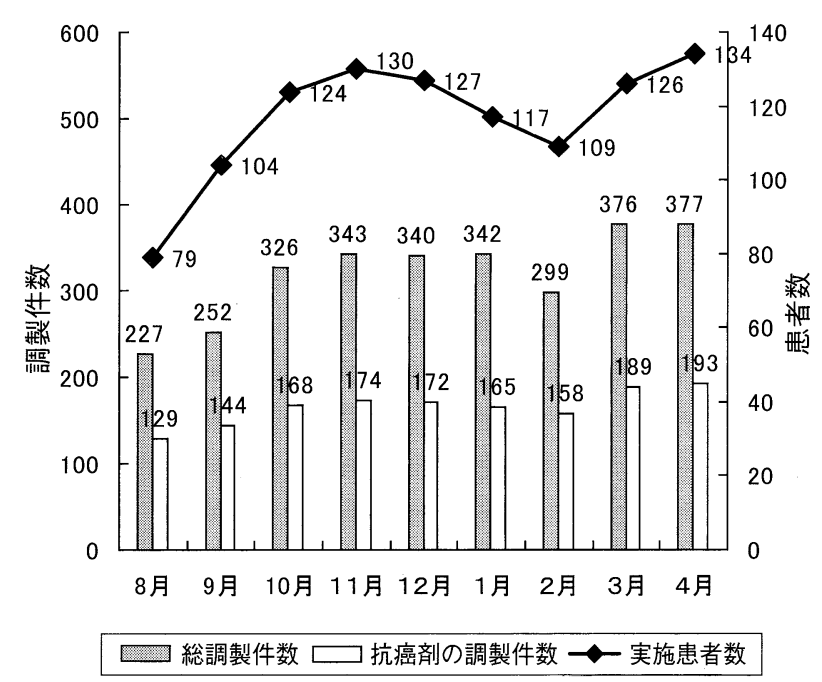

図 5. 実施延べ患者数および調製件数

義照会を行う場合もあり，医師・患者間でのコーディ ネートを行っていると考えている。ただし，依頼件数の 多い日は，患者に服薬指導をする時間を十分に取れない のが現状であり，効率的に患者の問題点を把握していく ことが今後の課題の一つである.

また，各診療科の看護師の間では，薬剤師が無菌的混 合調製を行うことにより，患者ケアの合間に調製を行う 看護師と異なりミスも少なく, 発泡性や溶解性など製郕 の特性を生かした調製ができ，患者に無菌的で安全な製 剤が投与され，しかも看護業務の負担が減ったことに関 して薬剤師に感謝する声があがっている。しかし，医師 から依頼されて処方せん控えの FAXを送ることが時間 的にも手技的にも煩雑であるとのクレームがでている。 また，予約処方せんと実施決定を知らせる処方せん控え
のFAX の内容が異なる場合がある。したがって, 現在 FAXの情報に替わる最終処方内容の確認手段を検討し

ている。

次に，コーディネート薬剤師業務手順書を事前に準備 し，患者情報記録に曜日ごとの異なる担当者が患者ごと に記載することによって，担当者が休みの時などに補助 に入る者も含め 6 名いるコーディネート薬剤師間で患者 情報の共有と手順の標準化が可能であった。

\section{2. 疑義照会などにおけるコーディネート薬剤師の評価} 疑義照会の総数は 9 力月間で50件であった(図6).投 与量に関する疑義照会が19件と一番多かった. 投与量に 関してはトラスッズマブの投与量算出のために体重が記 載されていない，あるいは，2 回目の投与量が 1 回目と 同じであったので医師に対して疑義照会を行った。その 他に，増量指示があるが患者が体調不良を訴えているの で医師に考慮していただき，増量取りやめにしてもらう 症例などがあった，日付に関しては，投与日と別の日の FAXを受信して疑義照会を行った。

また，規格に関してはドセタキセル20mg 4 バイアル でオーダが入っているのを $80 \mathrm{mg} 1$ バイアルに規格を変 更したことにより，医療経済へ貢献できた。副作用対 策・回避に関しては, 制吐剤追加やステロイド追加等を 医師にお願いした，その他としては，配合変化の回避や 点滴時間短縮のために配合変化のない前投薬の処方を 1 処方にまとめるなどがあった。

次に, カルテチェックや服薬指導などの患者情報記録 などより患者の利益に貢献した例を示す.

症例 1 ）臨床現場に必要な情報を看護師とともに作成 した症例

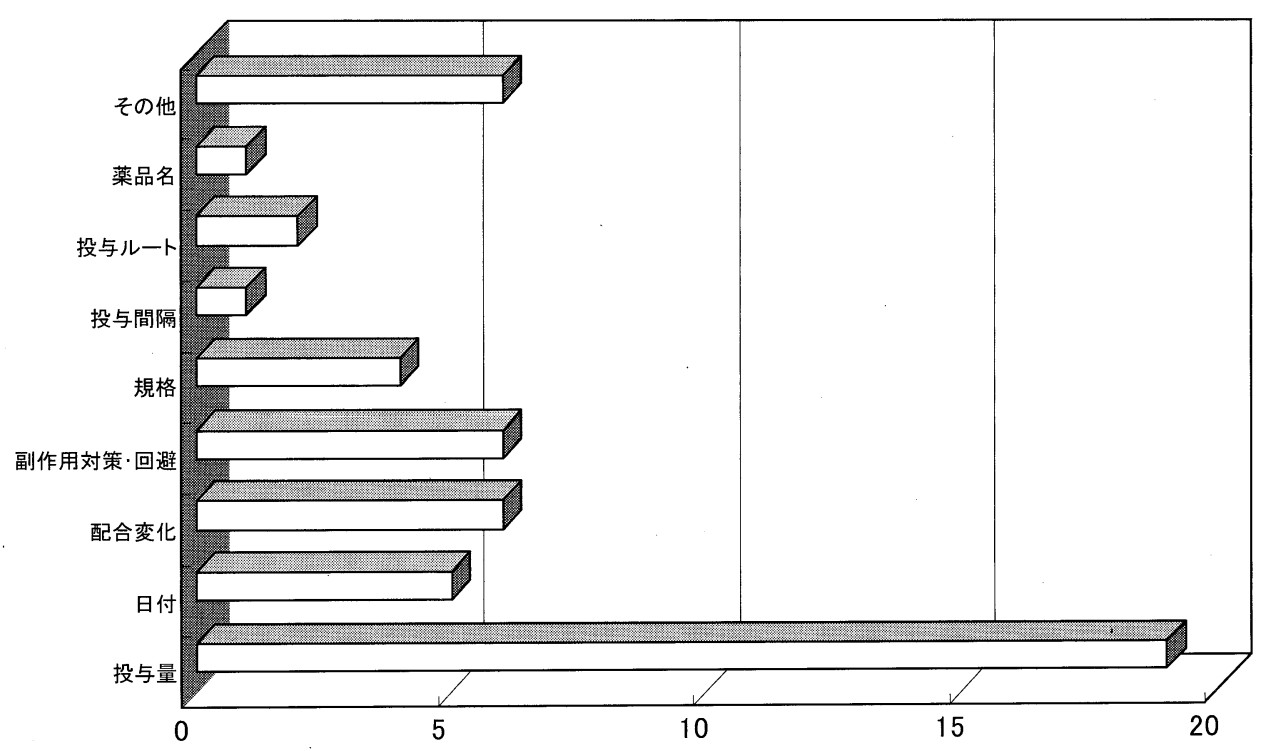

図 6. 疑義照会件数 
インタビューフォームなどの資料から，塩酸イリノテ カン $200 \mathrm{mg}$ (生食 $500 \mathrm{~mL}$ に溶解)にヘパリンナトリウム 5000 単位を配合すると24時間外観変化, 含量低下なしと いう情報が得られた。臨床現場で塩酸イリノテカンを動 注患者に投与する場合，溶解液量が少なく，ルート内で 白濁したとの情報を看護師から受けた。その後の調査 で，塩酸イリノテカン $50 \mathrm{mg}$ (生食 $40 \mathrm{~mL}$ に溶解)にヘパリ ンナトリウム 1000 単位配合で白濁することがわかった。

医師，看護師に報告し，へパリン投与前に生理食塩液で ルート洗浄することとした.

症例 2 ）患者の不安解消に貢献できた症例

患者からコーディネート薬剂師に爪の色素沈着の訴え があった。卵巣がんの化学療法(パクリタキセル十カル ボプラチン)施行中であり色素沈着はカルボプラチンに よるものと考えられた，薬剤師から主治医に報告し，皮 膚科受診となった。カルボプラチンによるものと診断が ついて，治療続行可能であることが皮膚科医より告げら れ，患者の不安が軽減した。

症例 3 ）副作用軽減に貢献できた症例

パクリタキセルからドセタキセルに変更後, 前投薬が 制吐剤だけになった。ドセタキセル開始後, 発熱, 皮膚 掻痒感などアレルギー症状がでていたので対策を調査し て，デキサメタゾンの追加を医師に提案した。デキサメ タゾンを追加後, 症状が軽減した.

疑義照会をコーディネート薬剤師が医師に対して行う 際，投与量や処方薬の追加などに関して医師と患者情報 を共有して協議し，患者の種々の問題に対策を講じて状 況を改善することが出来た，実際，コーディネート薬剤

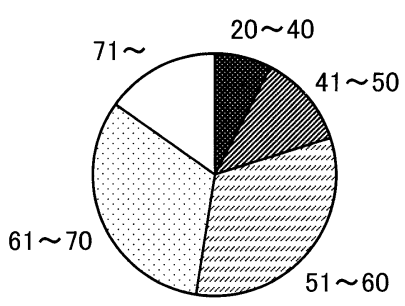

$a$,年齢分布

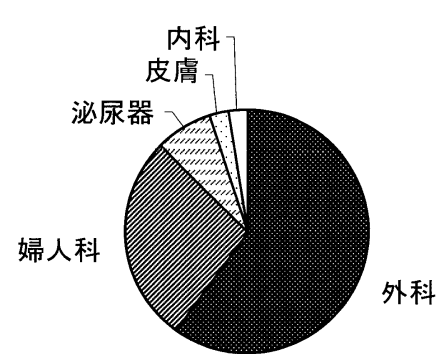

c,診療科
師を配置したことにより可能であった疑義照会は50件中 8 件であった．数種類ある前投薬の配合を確認し，1つ のボトルにまとめることで患者の総点滴時間の短縮に貢 献した。また，増量の指示があったが，患者の状態が悪 く医師と協議の結果, 増量が延期されたことがあった. さらに，その患者に必要な前投薬の処方し忘れに対応す ることもあった。これまでの処方鑑査を中心とした薬剤 師の関与から，患者を中心としたファーマシューティカ ルケアの実践への転換を示しているものと考えている. しかし，プロトコールの提出が更新のたびに完全ではな く, カルテの記載内容も医師や診療科によってばらつき がある状況で効率よい処方鑑査および疑義照会を行うこ とは，今後の課題である。

\section{3. 患者からのコーディネート薬剤師業務の評価}

回収できた40名の患者背景を図 7 に示す。50代から60 歳代の女性患者が多数を占めた。外来がん化学療法室で 治療を受ける回数が 5 回以上の患者が半数以上を占め た。

薬剤師に対する患者からの評価について検討すると， まず，外来がん化学療法において薬剤師が何を行ってい るか図 8 に示すが，薬剤師が搬送を行っていることを約 半数の患者が知っていたものの，コーディネート薬剤師 の業務内容は十分患者に浸透していないことがわかっ た。また，「薬を運んでいる薬剤師に望むこと」の結果 を図 9 に示す。このアンケートがコーディネート薬剤師 の業務内容を知るきっかけとなり，われわれも主に副作 用や生活上の注意点など，薬の情報を患者が求めている

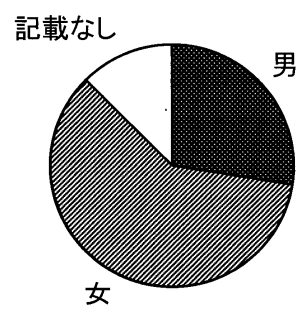

b,男女比

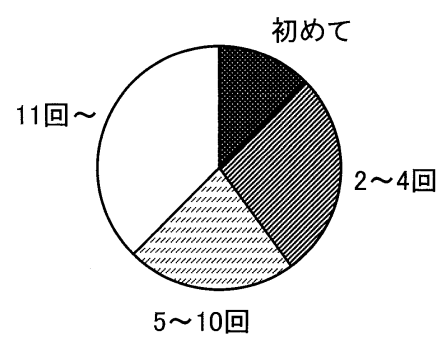

d,治療回数 (外来化学療法室)

図 7. 患者背景 


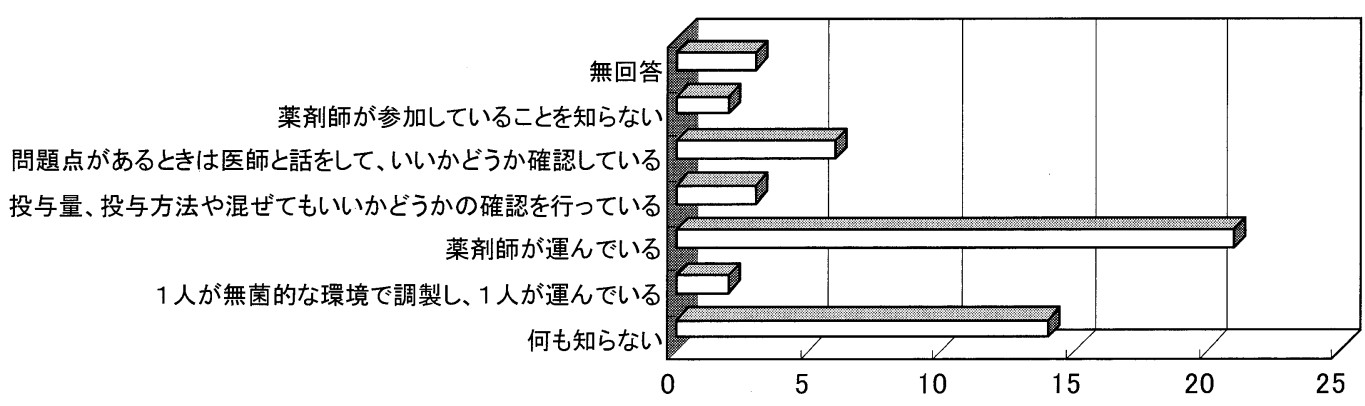

図 8. 外来化学療法室において薬剤師が行っている ことで知っていること (複数回答可)

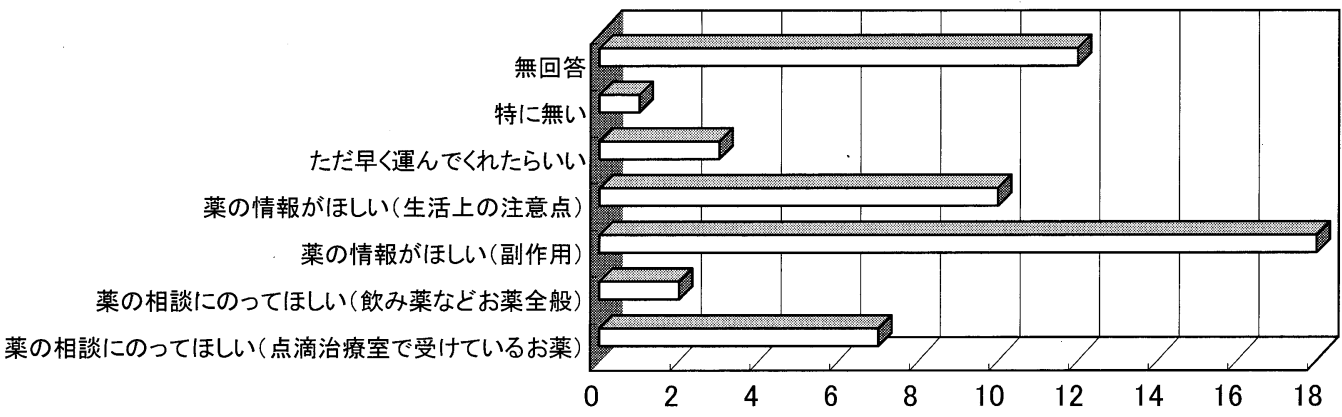

図 9.薬を運んでいる薬剤師(コーデイネート薬剤師)に 望むこと(複数回答可)

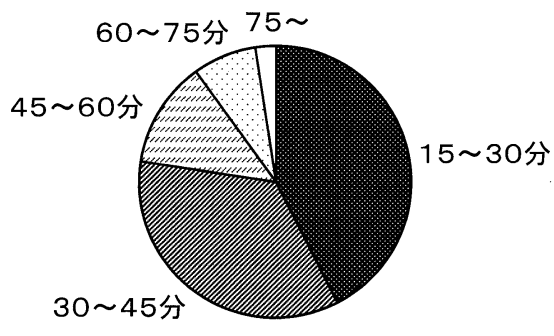

a,最大どのくらいまでなら待てますか?

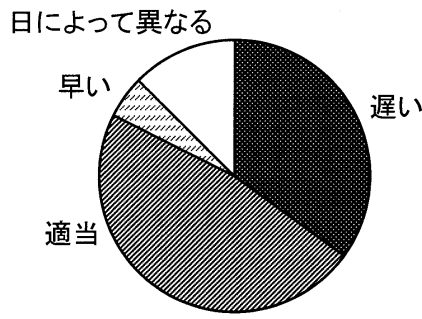

b,待ち時間についての印象

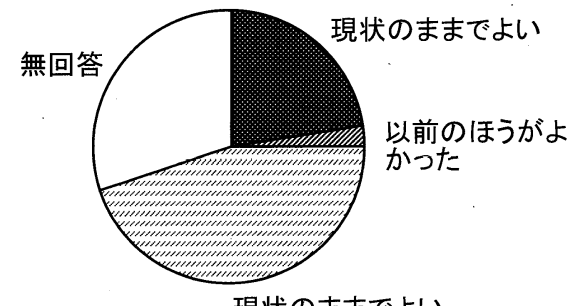

現状のままでよい

が、もう少し早くして

ほしい

c,待ち時間についての感想

図 10. 待ち時間に関する返答

ことが明らかになった。

待ち時間に関する結果を図10に示す，待ち時間に関し ては，アンケートの結果より約半数の患者が適当と答え
ていた。また，「待ち時間についての感想」の問いに， 「もとの外来診療室で行っていた以前の方がよかった」 と答えた患者は 1 名であり，FAX 受信から搬送完了ま 
でにかかる時間が予約オーダの有無に関わらず30分以内 であり，待ち時間は現状において特に大きな問題ではな いと考えられた。しかしながら，「現状のままでよいが， もう少し早くしてほしい」との回答が約半数であったこ ともあり，さらなる時間短縮の努力も必要である。

患者に自由にコメントをいただく目的で作成した「外 来がん化学療法室に薬剤師がいてよかったと思うことが ありましたら具体的に書いてください」という問いに対 しては，「専門家の関与で安心できる」「よく話を聞いて 下さいます」「親しみがあるので聞きたいことがある時は 聞こうと思います」という薬剤師に積極的な参加を求め る返答をいただいた。しかし，「よく分からない」「治療 に専念するだけです」といった返答もあった。

最後に，薬剤師による患者サービスが患者の間に十分 浸透しておらず，もっと知っていただくために積極的に 声をかけたり，パンフレットなどを用いて働きかけたり

していく必要があるものと考える.

\section{引用文献}

1) 二神幸次郎，柴田和彦，五味田裕，注射剂調剤一制 がん剂調剤の実践，日病薬誌，39,691-693 (2003).

2) 尾上雅英, 高柳和伸, 國正惇一, 岡野友信, 橋田亨, 二見高弘, 山崎誠二, 今村正之, 乾賢一, 抗癌剤の 適正使用への取り組み一薬剤部と腫瘍外科において 一, 医療薬学, 28, 321-326 (2002).

3）熊岡穣, 伏見康子, 有澤幸大, 西口工司, 松林照久, 西床京子，栄田敏之，西村善博，横山光宏，奥村勝 彦，癌化学療法に対する注射処方鑑査支援システム の構築と運用, 医療薬学, 29, 66-72 (2003).

4) G.J. Tanaka, J. Fujiwara, H. Kramer, A.B. Bredt, M. Wortmann, Justification and implementation of an oncology pharmacist practitioner in an HMO setting, Hospital Pharmacy, 20, 568-574 (1985).

5) D.A. Caselnova III, S.H. Dzierba, M.S. O’ neill, K. R. Dillon, P.C. Farley, Implementation clinical pharmacy services in an outpatient oncology clinic, American Journal of Hospital Pharmacy, 42, 1348-1352 (1985).

6) 松橋由美子，天野郁子，中村仁，鈴木常義，水柿道 直，癌化学療法への薬剤師の関わり〜婦人科病棟に おける治療前薬剤説明と副作用対策～，医薬ジャー ナル，37, 2465-2472 (2001). 